\title{
Proposed Financial Statement Changes By The FASB-IASB: Reactions From Chinese Accounting Majors
}

Don E. Giacomino, Ph.D., Marquette University, USA

Xin Li, M.A., Ph.D. Candidate, Beijing Institute of Technology, P.R. China

Michael D. Akers, Ph.D., Marquette University, USA

\begin{abstract}
Based on concerns regarding the usefulness of the current format of the financial statements to assist users in making decisions and as part of the convergence efforts of the IAS and GAAP, the Financial Accounting Standards Board (FASB) and the International Accounting Standards Board (IASB) created a joint project (2004) on financial statement presentation which resulted in the publication of their joint Discussion Paper, Preliminary View on Financial Statement Presentation. Prior research has examined the response of academics, preparers (CPAs) and US accounting students (future preparers). This paper extends that research by examining the reaction of Chinese accounting students, future international preparers. While the Chinese students show greater support for the proposals of the FASB and IASB than the US students, the support is moderate. We believe the stronger support of the Chinese students for the proposals is primarily related to cultural issues as compared to the substance of the proposals. The findings of this study are consistent with findings of prior research. While the project is currently on hold the findings of this study and prior research suggests that the FASB and IASB should consider whether the proposals appropriately address the concerns in making the decision to renew this project.
\end{abstract}

Keywords: FASB-IASB; Conceptual Framework Project; Chinese Educators

\section{INTRODUCTION}

n response to concerns about the inadequacy of the current formats of financial statements to assist users with their decisions and as part of the convergence efforts of the IAS and GAAP, the Financial Accounting Standards Board (FASB) and the International Accounting Standards Board (IASB) created a joint project (2004) on financial statement presentation. The boards' goal of this project is to help users of the financial statements in making decisions by improving the usefulness of the information in the financial statements. While the Boards conducted research and outreach activities during 2008-2010 and additional research/outreach will be conducted, the project is currently inactive. Work will resume when the boards have the capacity to do so. In the meantime, the FASB has indicated it would welcome input.

SFAC No. 8 (OB 1), states "The main objective of general purpose financial reporting is to provide financial information about the reporting entity that is useful to existing and potential investors, lenders, and other creditors in making decisions about providing resources to the entity". Therefore, the purpose of our study is to determine the opinions of those users. Specifically, we obtain the reactions of Chinese accounting majors on specific changes that are proposed by the Boards. We surveyed current accounting students (undergraduate-juniors and seniors and graduate-Masters students) at the Beijing Institute of Technology. The findings of this study are compared to the results of two prior studies: 1) Shough (2009) surveyed CPAs to obtain their perceptions of the proposed changes and 2) Giacomino and Akers (2010) surveyed US accounting and finance majors. This additional input from international students, along with the comparison of the Shough (2009) and Giacomino and Akers (2010) findings, provides more information about the acceptability of the Boards' proposals. 
The first section of the paper presents an overview of the financial statement format proposals from the joint boards (FASB and IASB) in their Discussion Paper and subsequent research/outreach activities. The reaction of US Accounting academicians and research that has examined the reactions of CPAs and US accounting students are examined in section two in order to provide a frame of reference for the findings of this study. Section three discusses the survey of the undergraduate and graduate accounting students at the Beijing Institute of Technology and compares the results to the responses of the CPAs and the US accounting students. The last section is devoted to a summary and conclusions, including implications for acceptance of the proposed financial statement formats as well as the limitations and contributions of the paper.

\section{OVERVIEW: FINANCIAL STATEMENT PRESENTATION-JOINT PROJECT OF THE FASB AND IASB}

On June 30, 2008, the Boards issued their joint Discussion Paper, Preliminary View on Financial Statement Presentation. In the Discussion Paper, the Boards propose a new model (format) for presenting financial statements. Their intention is to improve the usefulness of financial statements for decisions by users of the statements. Under the proposals, similar categories (Exhibit 2) of activities along the lines of the activities in the current Statement of Cash Flows will be used to format the three financial statements: Statement of Financial Position (Exhibit2), Statement of Comprehensive Income (Exhibit 3), and Statement of Cash Flows (Exhibit 4). Those categories are Business, Financing, Income Taxes, Discontinued Operations and Equity (Other Comprehensive Income for the Statement of Income). This represents a major departure from the current formats for each of the statements. In addition, the Discussion Paper proposes a Reconciliation Statement that reconciles cash flows to comprehensive income (Exhibit 5). While Exhibits 1 through 5 have appeared in prior literature, we are presenting again as these items relate to this study. The boards solicited written comments in response to the proposed financial statement presentation and April 19, 2009 was the deadline for comments. As of April 2010, the FASB has tentatively decided to replace the reconciliation schedule with an analysis of the changes in balances of all significant asset and liability items.

During the comment period, the Boards had 30 companies participate in a field test of the proposals to: (1) determine whether the proposed presentation model improves usefulness of the information to users in making their decisions as capital providers and (2) understand the costs of implementation and identify unintended consequences in applying the model. In their July 14, 2009 paper, the technical staffs of the FAF and IASCF discuss the purpose and background for the field test and the results of the survey.

In July 2009, the Joint International Group (JIG) and the Financial Institutions Advisory Group (FIAG) met to discuss the Discussion Paper and the results of field testing and to provide feedback on possible alternatives. In summary, a majority of companies that implemented the proposed model believe that the recast statements communicate their results the same or worse than the non-recast statements. In addition, the staff (IASB and FASB) believes that the benefit of by-nature information on the face of the statements is not readily evident. The staff also questions whether the increase in line items (on the proposed model) equates to an increase in usefulness of the information presented. Finally, the staff also questions the effectiveness of the proposed definitions of the sections and categories and the disaggregation guidance.

Using the feedback from their outreach activities the boards prepared a staff draft of an exposure draft of financial statement presentation in April 2010. The staff draft was posted on each board's website. The staff draft reflects their cumulative decisions on financial statement presentation and will be used for additional outreach activities which will focus on two areas: 1) perceived benefits and costs and 2) implications for financial reporting by financial services entities. Although the project is currently inactive, the boards plan to conduct five additional outreach activities: 1) General outreach-staff will meet with a variety of constituents including standard setters, investor representatives and preparers from Europe; 2) investor outreach-staff will ask financial statement users from a variety of countries to assess how the benefits of the changes and the impact on resource allocation; 3 ) field visits-staff will ask preparers (individual companies) to assess the effort/costs of the changes; 4) field testingfinancial service and nonpublic entities will be asked to recast financial statements for two years using the proposed changes and those companies that participated in the field testing of the 2008 Discussion Paper proposals will be asked to test only the current proposals that are now different; and 5) cash flow information-several different activities will be used and will include information from field testing, discussion with analysts that are familiar with 
using cash flow statements that use the direct method and academic studies that examine the Statement of Cash Flows.

\title{
REACTIONS OF ACADEMICS, PREPARERS AND FUTURE PREPARER/USER GROUPS
}

\author{
American Accounting Association Response
}

The Financial Accounting Standards Committee of the American Accounting Association (AAA FASC, 2010) responded to the Discussion Paper in a March 2010 article published in Accounting Horizons. While the committee concluded that the project has the potential to improve the usefulness of financial reporting, the committee identified potential concerns about the timing of the proposal, challenges for XBRL and data tag-base reports, vagueness of disaggregation, and the need for a financial leverage objective. The committee recommends (1) that the "business" caption be changed to "operating" and (2) presentation of discontinued operations in relevant categories rather than in a separate section.

\section{Reaction from CPAs}

In 2009, Stuart Shough conducted a survey of CPAs to determine their receptiveness to the changes proposed in the Discussion Paper. Shough obtained the opinions of a sample of 605 CPAs in response to 19 questions about specific proposals for changes in the aggregations and categories of activities. Based on the answers from the respondents, Shough (2009) concluded that the proposed changes in financial statement presentation wouldn't help users of the financial statements in making decisions by improving the usefulness of the information in the financial statements. Shough's (2009) results are presented in Table 1 along with the findings of this study. An examination of Shough's findings indicates strong support (80\% agreement) for only one item (question 5)separate section for discontinued operations. The questions with the next highest support were question 3 (separate equity from financing), question 12 (restrict financing section to financial liabilities per IFRS \& GAAP, and question 15 (prepare single statement of comprehensive income) with 64\% support; moderate support.

\section{Reaction from U. S. Accounting Students}

Neither the field study by the FASB-IASB Boards nor Shough's study involved the main users, who are the main target audience of the FASB and IASB, of the financial statements -- equity investors and creditors. Giacomino and Akers (2010) conducted a study designed to obtain the opinions of future equity and credit analysts. They used the survey instrument that Shough used in his study of CPAs to obtain the opinion of some future preparers, auditors and users of corporate financial statements. Giacomino and Akers (2010) surveyed two student groups: (1) accounting majors (seniors and graduate students) and finance majors (applied investment management majors, juniors and seniors) at a private, Midwestern university in the United States. Their findings are also presented in Table 1 along with the findings of this study. Overall, Giacomino and Akers found better support (1 item had $93 \%$ support, followed by 6 items with support ranging from $75 \%$ to $70 \%$ ) for the proposals by the students as compared to the CPAs. Such support, however, is not strong support. Consistent with Shough's findings, Giacomino and Akers found the greatest support for question 5 (93\%, separate section for discontinued operations). Both CPAs and U.S. accounting students don't believe the management approach (question 7) provides a more useful view of the entity.

\section{Reaction from Chinese Accounting Students}

We distributed the survey instrument and proposed financial statements to accounting majors (junior, senior, graduate- $1^{\text {st }}$ and $2^{\text {nd }}$ year) in the classes of one of the authors at the Beijing Institute of Technology. The instructor explained the financial statements (Exhibits 1 through 5) and the proposed changes. The students were then given 40 minutes to read the financial statements and respond to the survey in English. While the students were advised to complete the survey in English, a Chinese version was provided for their reference. Participation in this project was voluntary and not all students participated. All of the surveys were completed in class except for the $2^{\text {nd }}$ year graduate students. Due to the lateness of the day, the $2^{\text {nd }}$ year graduate students were allowed to complete the surveys at home and return them the next day. 
The following table provides a breakdown for the 101 respondents to the survey:

$\underline{\text { Students }}$

Accounting majors (juniors)

Accounting majors (seniors)

Accounting graduate students $\left(1^{\text {st }}\right.$ year $)$

Accounting graduate students $\left(2^{\text {nd }}\right.$ year $)$

Total

\begin{tabular}{l}
$\frac{\mathrm{N}}{33}$ \\
24 \\
23 \\
$\underline{21}$ \\
$\underline{\underline{101}}$ \\
\hline
\end{tabular}

Table 1 provides data for responses from surveys of U.S. and Chinese accounting majors. Overall, Chinese students are more accepting of the Boards' proposals as 9 of the responses show support of $73 \%$ or higher (range- 73 to 93) with the highest support for question 1 (93\%, proposed format would improve decision usefulness) and question 5 (93\%, separate section for discontinued operations). Specifically, for 14 of the 20 questions, a higher percentage of Chinese students agree with the proposals than US students and CPAs. One explanation for this stronger support by the Chinese accounting students is that Chinese students highly respect authority and are more willing to accept changes from authority.

Another interesting difference between the Chinese, U.S. students' and CPA responses relates to questions \#5 and \#6. Question \# 5 asks if the respondent agrees with having a separate section for discontinued operations, while question \#6 asks if the respondent agrees with disclosing discontinued operations in the relevant categories. In other words, if a respondent agrees with having a separate section for discontinued operations, we would expect that respondent to disagree with disclosure in the relevant categories. The high agreement percentages for Chinese students for both questions might suggest that the Chinese students did not understand what question \#6 was asking.

Table 3 provides response data for each of the student groups (graduate and undergraduate) at the Chinese university. Overall, the graduate students were more accepting (15 of 20 questions) of the Boards' proposals than were the undergraduates. Since the graduate students are older we aren't surprised that they are more supportive than the undergraduates. Once again, the greatest support is for question 5 - Separate section for discontinued operations.

\section{SUMMARY AND CONCLUSIONS}

Four years ago, the FASB and IASB prepared a joint discussion paper that proposes major changes to the form and content of financial statements. While awaiting comments on the Discussion Paper, these groups had 30 companies field test the proposals. The field-test process has provided the FASB and IASB with useful information for considering revisions to the proposals and issues that needed to be addressed. Academia (Financial Accounting Standards Committee of the American Accounting Association) has a number of concerns regarding timing, user learning issues and impediments to learning, objectives and terminology and categorizing activities and assets and liabilities. A survey of 605 CPAs found that many of the CPAs show concerns about the usefulness of the proposed model. Results from surveys of future users/preparers in the United States and China show that with the exception one item, separate section for discontinued operations, limited support for the proposals. While the Chinese students show overall greater support for the proposals, we believe such support is because the Chinese culture places more respect for and deference to authority than in the United States. We believe these findings suggest three possible explanations: 1) Benefits of the proposals don't exceed the costs. Preparer's will most likely incur tremendous cost to their accounting information systems in order to comply with the changes and such changes could trigger additional costs if leases or long-term debt agreements are affected by the proposals; 2) Proposals don't enhance the usefulness of the presentation of the information in the financial statement and therefore won't enhance the users' decision making. and 3) Possible lack of understanding of the proposals by CPAs and Accounting students implies such changes will necessitate considerable educational efforts. Considering the lack of financial literacy that currently exists, this is an issue that should be overlooked. 


\section{LIMITATIONS OF THE STUDY}

There are two limitations of the study. First, the Chinese accounting majors that completed the survey were students in the classes of one of the authors of this paper. While we have no reason to believe our findings aren't representative of Chinese accounting students, our sample wasn't randomly selected, thus our results might not be representative of all Chinese accounting students. Second, although a Chinese version of the survey was provided for reference, the students were asked to complete the survey in English and there could have been some misunderstanding of the questions as evidenced in the inconsistent results of questions 5 and 6.

\section{CONTRIBUTIONS}

There are two primary contributions of this paper. First, this paper provides an international perspective of future preparers/users and this is consistent with the planned outreach activities of the FASB and IASB. Second, the findings of this study, when compared with the CPAs and U.S. accounting student responses, illustrates moderate, at best, support for the proposals. The FASB and IASB should consider the results of these studies (CPAs, US accounting students, Chinese accounting students) as they continue to move toward the possibility of new requirements for presenting financial statements. Many CPAs do serve as users of the financial statements - in the context of auditing, corporate management, corporate financial reporting and consulting and students will be future users or preparers of financial statements and accounting students represent future preparers/users of the financial statements.

\section{AUTHORS' INFORMATION}

Don E. Giacomino, Ph.D., CPA, Professor and Donald \& Beverly Flynn Chair Holder, Department of Accounting, College of Business Administration, Marquette University, Milwaukee, WI 53201 USA. E-mail: Don.giacomino@marquette.edu

Xin Li, M.A., Ph.D. Candidate (Management), SME Lecturer, Department of Accounting, School of Management and Economics, Beijing Institute of Technology, Beijing, P.R. China. E-mail: Lixinsheila@bit.edu.cn

Michael D. Akers, Ph.D., CPA, CMA, CFE, Chair and Charles T. Horngren Professor of Accounting, Department of Accounting, College of Business Administration, Marquette University, Milwaukee, WI 53201 USA. E-mail: Michael.akers@marquette.edu (Corresponding author)

\section{REFERENCES}

1. American Accounting Association, 2010, "Response to the Financial Accounting Standards Boards' and the International Accounting Standards Boards' Joint Discussion Paper Entitled Preliminary Views on Financial Statement Presentation", Accounting Horizons, Vol. No. 1, March 2010, pp. 149-158.

2. Giacomino, Don E. and Michael D. Akers, "Proposed Financial Statement Changes: Reactions to the FASB-IASB Discussion Paper," Journal of Business and Economics Research, Volume 8, Number 7, (July 2010), pp. 59-74.

3. Shough, Stewart, "What the CPAs Think about the Proposed Financial Statement Presentation", Journal of Business and Economic Research, Volume 7, Number 11, November 2009, pp. 103-112. 
Table 1

Responses to Discussion Paper Proposals Percentage of Respondents Answering "Yes"

Question

1. Would proposed format improve decision usefulness?

2. Grouping data by activities is more useful?

3. Separate equity from financing?

4. Include equity in financing?

5. Separate section for discontinued operations?

6. Disclose discontinued operations in relevant categories?

7. Management approach provides more useful view of entity?

8. Reduced comparability (of management approach) outweighs benefits?

9. Separating business and financing makes ratio computation easier?

10. Accept definitions: business section, operating and investing categories?

11. Accept definitions: financing section and relevant categories?

12. Restrict financing section to financial liabilities per IFRS \& GAAP?

13. Eliminate cash equivalents from cash; show as short-term investments?

14. Disaggregate assets and liabilities measured on different bases?

15. Prepare single statement of comprehensive income?

16. Direct method more useful for presenting cash flows from operations?

17. Direct method more consistent with cohesiveness and disaggregation?

18. Include indirect method information in the proposed reconciliation?

19. Reconciliation statement increases understanding of future cash flows?

20. Should FASB apply the proposed model to nonpublic entities? $*$ The bold print indicates questions on which the Chinese students are more in agreement with the proposed changes than are the
U. S. students. Questions 3 and 4 were one question in Shough's study.

$\underline{\text { Students }} \underline{\text { CPina }}$ U.S.

$\mathbf{9 1 \%} \quad 74 \% \quad 38 \%$

$\mathbf{7 8 \%} \quad 63 \% \quad 48 \%$

$64 \% \quad 64 \% \quad 64 \%$

$\mathbf{5 4 \%} \quad 41 \% \quad \sim$

$93 \% \quad 93 \% \quad 80 \%$

$\mathbf{8 3 \%} \quad 28 \% \quad 23 \%$

$\mathbf{5 4 \%} \quad 32 \% \quad 37 \%$

$\mathbf{4 5 \%} \quad 69 \% \quad 61 \%$

$\mathbf{6 9 \%} \quad 57 \% \quad 36 \%$

$53 \% \quad 57 \% \quad 47 \%$

$67 \% \quad 74 \% \quad 45 \%$

$\mathbf{4 0 \%} \quad 67 \% \quad 64 \%$

$\mathbf{6 7 \%} \quad 53 \% \quad 54 \%$

$73 \% \quad 75 \% \quad 50 \%$

$48 \% \quad 71 \% \quad 64 \%$

$\mathbf{7 7 \%} \quad 69 \% \quad 59 \%$

$\mathbf{8 1 \%} \quad 64 \% \quad 58 \%$

$\mathbf{7 9 \%} \quad 70 \% \quad 52 \%$

$\mathbf{7 6 \%} \quad 75 \% \quad 51 \%$

$\mathbf{6 0 \%} \quad 58 \% \quad 23 \%$ 
Table 2

Survey Regarding FASB-IASB Discussion Paper

Q\# Question

Would the objectives of financial statement presentation proposed in Exhibit 1 improve the usefulness of the information provided in an entity's financial statements by helping users make better decisions in their capacity as capital providers?

2 Would the objectives of financial statement presentation proposed (Balance Sheet) would group data by major activities (operating, investing, and financing) not by assets, liabilities and equity as at present. Would the separation of business activities from financing activities provide information that is more decision useful than that provided in the financial statement formats used today?

The Boards concluded that information about the financing of business activities should be shown according to the source. The financing section would include non-owner sources of financing and the equity section would display information form owner sources.

$3 \quad$ Should equity be presented as a section separate from the financing section?

Should equity be included as a category in the financing section?

In the Statement of Financial Position, information about discontinued operation would be shown separately from its continuing business and financing activities.

In the proposed presentation model, an entity would present its discontinued operations in a separate section.

$5 \quad$ Does this presentation provide decision useful information?

$6 \quad$ Instead of presenting this information in a separate section, should an entity present information about its discontinued operations in the relevant categories (operating, investing, financing assets and financing liabilities?

Management would classify its assets and liabilities into the sections and categories in the statement of financial position based on how management thinks the asset or liability is used within the entity. This classification by management would determine the classification in the statements of comprehensive income and cash flows. The proposed presentation model relies on a management approach to relies on a management approach to classification of assets and liabilities and the related changes in those items In the sections and categories in order to reflect the way an item is used within the entity or its reportable segment.

$7 \quad$ Would a management approach provide the most useful view of an entity to users of its financial statements?

Would the potential for reduced comparability of financial statements resulting from a management approach to classification outweigh the benefits of that approach?

The paper (Boards' proposal) proposes that both assets and liabilities should be presented in the business section and in the financing section of the statement of financial position.

$9 \quad$ Would this change in presentation coupled with the separation of business and financing activities in the statements of comprehensive income and cash flows make it easier for users to calculate some key financial ratios for an entity's business activities or its financing activities? The Discussion Paper states that the business section should include assets and liabilities that management views as part of its continuing business activities of producing goods or providing services with customers, suppliers and employees. The operating category should include assets and liabilities that management views as related to the central purpose for which the entity is in business and the investing category should include assets and liabilities that management views as unrelated to the central purpose for which the entity is in business.

Yes $\quad \underline{\text { No }}$

$-$ $-$ 
10 Are the business section and the operating and investing categories within that section defined appropriately?

The financing section should include financial assets and financial liabilities that management views as part of the financing of the entity's

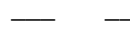

business and other activities. The liabilities would normally result from capital-raising activities to fund business activities.

11 Are the financing section and the financing assets and financing liabilities categories within that section defined appropriately?

12 Should the financing section be restricted to financial liabilities as defined in IFRS and U.S. GAAP as proposed?

The Discussion Paper proposes the elimination of cash equivalents. These types of securities should be shown as short-term investments and not presented as part of cash in the statement of financial position. The Discussion Paper proposes that cash equivalents should be presented and classified in a manner similar to other short-term investments, not a part of cash.

13 Do you agree?

The Boards required disaggregation of assets and liabilities according their measurement bases and present them on separate lines in

the statement of financial position. For example, securities measured at amortized cost and securities measured at fair value should be shown on separate lines.

14 An entity should present its similar assets and liabilities that are measured on different bases on separate lines in the statement of financial position.

Would this disaggregation provide information that is more useful than a presentation that permits line items to include similar assets and liabilities measured on different bases?

There is to be only a single Statement of Comprehensive Income (Exhibit 3) of which net income or loss would be a subtotal. Comprehensive

income and other comprehensive income would no longer be allowed to be shown in the statement of changes in stockholder's equity.

15 Should an entity present comprehensive income and its components in a single statement of comprehensive income as proposed?

There are two major changes in the proposed format of the Statement of Cash Flows (Exhibit 4). Firstly, the elimination of cash equivalents and secondly, the entity would use the direct method to present its cash receipts and cash payments. The use of the indirect method would no longer be allowed for the operating activities section of the statement of cash flows.

16 The paper proposed that an entity should use the direct method of presenting cash flows in the statement of cash flows. Would the direct method provide information that is decision useful?

17 Is the direct method more consistent with the proposed cohesiveness and disaggregation objective than the indirect method?

18 Would the information currently provided using the indirect method to present operating cash flows be provided in the proposed reconciliation schedule?

A new Reconciliation Schedule (Exhibit 5) will be presented in the notes to the financial statements. This schedule reconciles cash flows to comprehensive income and disaggregates comprehensive income into four components: (a) cash received or paid other than in transaction with owners, (b) accruals other than remeasurement, (c) remeasurements that are recurring fair value changes or valuation adjustments, and (d) remeasurement that are not recurring fair value changes or valuation adjustments.

19 Would the proposed reconciliation schedule increase users' understanding of the amount, timing and uncertainty of an entity's future cash flows?

The proposed financial statements presentation would apply to all entities except for not-for-profit entities and nonpublic entities. The

Discussion Paper states that the FASB has not considered explicitly whether this model should apply to nonpublic entities.

Do you think the FASB should consider applying the proposed model nonpublic entities? 
Table 3

Responses to Discussion Paper Proposals Chinese Students Percentage of Respondents Answering "Yes"

\section{Question}

1. Would proposed format improve decision usefulness?

2. Grouping data by activities is more useful?

3. Separate equity from financing?

4. Include equity in financing?

5. Separate section for discontinued operations?

6. Disclose discontinued operations in relevant categories?

7. Management approach provides more useful view of entity?

8. Reduced comparability (of management approach) outweighs benefits?

9. Separating business and financing makes ratio computation easier?

10. Accept definitions: business section, operating and investing categories?

11. Accept definitions: financing section and relevant categories?

12. Restrict financing section to financial liabilities per IFRS \& GAAP?

13. Eliminate cash equivalents from cash; show as short-term investments?

14. Disaggregate assets and liabilities measured on different bases?

15. Prepare single statement of comprehensive income?

16. Direct method more useful for presenting cash flows from operations?

17. Direct method more consistent with cohesiveness and disaggregation?

18. Include indirect method information in the proposed reconciliation?

19. Reconciliation statement increases understanding of future cash flows?

20. Should FASB apply the proposed model to nonpublic entities?

\begin{tabular}{lll}
\multicolumn{2}{c}{ Students } & \\
Grad & $\mathbf{U G}$ & Total \\
$\mathbf{n = 4 4}$ & $\underline{\mathbf{n}=\mathbf{5 7}}$ & $\underline{\mathbf{n}=\mathbf{1 0 1}}$
\end{tabular}

95\%* $\quad \overline{86 \%} \quad \overline{91 \%}$

$\mathbf{8 6} \% \quad 72 \% \quad 78 \%$

$\mathbf{7 5} \% \quad 56 \% \quad 64 \%$

$50 \% \quad \mathbf{5 8} \% \quad 54 \%$

$93 \% \quad \mathbf{9 4} \% \quad 93 \%$

$\mathbf{9 5} \% \quad 74 \% \quad 83 \%$

$\mathbf{5 7} \% \quad 53 \% \quad 54 \%$

$\mathbf{3 4} \% \quad 53 \% \quad 45 \%$

$68 \% \quad \mathbf{7 0} \% \quad 69 \%$

$66 \% \quad 44 \% \quad 53 \%$

$\mathbf{8 0} \% \quad 58 \% \quad 67 \%$

$\mathbf{4 8} \% \quad 33 \% \quad 40 \%$

$59 \% \quad \mathbf{7 4} \% \quad 67 \%$

$\mathbf{7 7} \% \quad 70 \% \quad 73 \%$

$\mathbf{5 5} \% \quad 42 \% \quad 48 \%$

$\mathbf{8 0} \% \quad 75 \% \quad 77 \%$

$\mathbf{9 3} \% \quad 72 \% \quad 81 \%$

$\mathbf{8 4} \% \quad 75 \% \quad 79 \%$

$70 \% \quad 81 \% \quad 76 \%$

$\mathbf{7 3} \% \quad 51 \% \quad 60 \%$

*Bold numbers indicate higher agreement with Boards' proposal

\begin{tabular}{|lll|}
\hline \multicolumn{2}{|l|}{ EXHIBIT 1 } & \\
\hline \multicolumn{3}{|l|}{ Working Format for Presenting Information in the Financial Statements } \\
\hline Statement of & Statement of & Statement of \\
\hline Financial Position & Comprehensive Income & Cash Flows \\
\hline Business & Business & Business \\
\hline - Operating Assets \& Liabilities & - Operating Income \& Expense & - Operating Cash Flows \\
\hline - Investing Assets \& Liabilities & - Investing Income \& Expense & - Investing Cash Flows \\
\hline & & \\
\hline Financing & Financing & Financing \\
\hline - Financing Assets & - Financing Asset Income & - Financing Asset Cash Flows \\
\hline - Financing Liabilities & - Financial Liability Expense & - Financing Liability Cash Flows \\
\hline & & Income Taxes \\
\hline Income Taxes & Income Taxes (related to \\
\hline & business and financing) \\
\hline & \\
\hline Discontinued Operations & Discontinued Operations, \\
\hline & Net of Tax \\
\hline & \\
\hline Equity & Other Comprehensive Income, Equity \\
\hline
\end{tabular}


EXHIBIT 2

Hutch Manufacturing Co. Statements of Financial Position

\begin{tabular}{|c|c|c|c|c|}
\hline & & 2007 & & 2008 \\
\hline \multicolumn{5}{|c|}{ BUSINESS } \\
\hline \multicolumn{5}{|c|}{ Operating assets and liabilities } \\
\hline \multicolumn{5}{|c|}{ Short term } \\
\hline & Receivables & 68,000 & $\$$ & 54,000 \\
\hline & Less: Allowance for bad debts & $(2,000)$ & & $(1,000)$ \\
\hline & Inventories & 26,000 & & 20,000 \\
\hline & Prepaid expenses & 19,000 & & 24,000 \\
\hline & Short-term assets & 111,000 & & 97,000 \\
\hline & Accounts payable & $(19,000)$ & & $(16,000)$ \\
\hline & Accrued liabilities and other & $(56,000)$ & & $(74,000)$ \\
\hline & Short-term liabilities & $(75,000)$ & & $(90,000)$ \\
\hline \multicolumn{5}{|c|}{ Long term } \\
\hline & Property, plant, and equipment & 34,000 & & 24,000 \\
\hline & Less: Accumulated depreciation & $(9,000)$ & & $(6,000)$ \\
\hline & Goodwill & 20,000 & & 25,000 \\
\hline & Intangibles & 82,000 & & 82,000 \\
\hline & Less: Accumulated amortization & $(21,000)$ & & $(14,000)$ \\
\hline & Other assets and liabilities, net & $(5,000)$ & & $(3,000)$ \\
\hline & Net long-term assets & 101,000 & & 108,000 \\
\hline & Net operating assets & 137,000 & $\$$ & 115,000 \\
\hline \multicolumn{5}{|c|}{ Investing assets and liabilities } \\
\hline \multicolumn{5}{|c|}{ Long term } \\
\hline & Available-for-sale securities & 2,000 & & 3,000 \\
\hline & Investment in affiliate - equity method & $\underline{6,000}$ & & $\underline{5,000}$ \\
\hline & Total investing assets & 8,000 & $\$$ & 8,000 \\
\hline & Net business assets & 145,000 & $\$$ & 123,000 \\
\hline FINA & NCING & & & \\
\hline Fina & ncing assets & & & \\
\hline Shor & t term & $\underline{92,000}$ & & 94,000 \\
\hline & Cash & 92,000 & & 94,000 \\
\hline & Total financing assets & & & \\
\hline Fina & ncing liabilities & & & \\
\hline Shor & t term & & & \\
\hline & Dividends payable & $(3,000)$ & & $(3,000)$ \\
\hline & Short-term debt and current portion of long-term & $(14,000)$ & & $(1,000)$ \\
\hline & Short-term financing liabilities & $\overline{(17,000)}$ & & $(4,000)$ \\
\hline Long & term & & & \\
\hline & Long-term debt & $(71,000)$ & & $(49,000)$ \\
\hline & Long-term financing liabilities & $(71,000)$ & & $(49,000)$ \\
\hline & Net financing assets & 4,000 & $\$$ & 41,000 \\
\hline INCC & DME TAXES & & & \\
\hline Shor & t term & & & \\
\hline & Income taxes payable & $(8,000)$ & & $(12,000)$ \\
\hline Long & term & & & \\
\hline & Deferred tax assets, net & 10,500 & & 13,500 \\
\hline & Net income tax assets & 2,500 & $\$$ & 1,500 \\
\hline DISC & ONTINUED OPERATIONS & & & \\
\hline Asse & ts classified as held for sale & 20,000 & & 22,000 \\
\hline Liabi & lities classified as held for sale & $(8,000)$ & & $(8,000)$ \\
\hline & Net assets held for sale & 12,000 & $\$$ & 14,000 \\
\hline EQU & ITY & & & \\
\hline & Common stock and additional paid in capital & $(47,000)$ & & $(40,000)$ \\
\hline & Treasury stock & 142,000 & & 97,000 \\
\hline & Retained earnings & $(250,750)$ & & $(228,000)$ \\
\hline & Accumulated other comprehensive income & $(7,750)$ & & $(8,500)$ \\
\hline & Total equity & $(163,500)$ & $\$$ & $(179,500)$ \\
\hline
\end{tabular}




\section{EXHIBIT 3}

Hutch Manufacturing Co. Consolidated Statements of Comprehensive Income

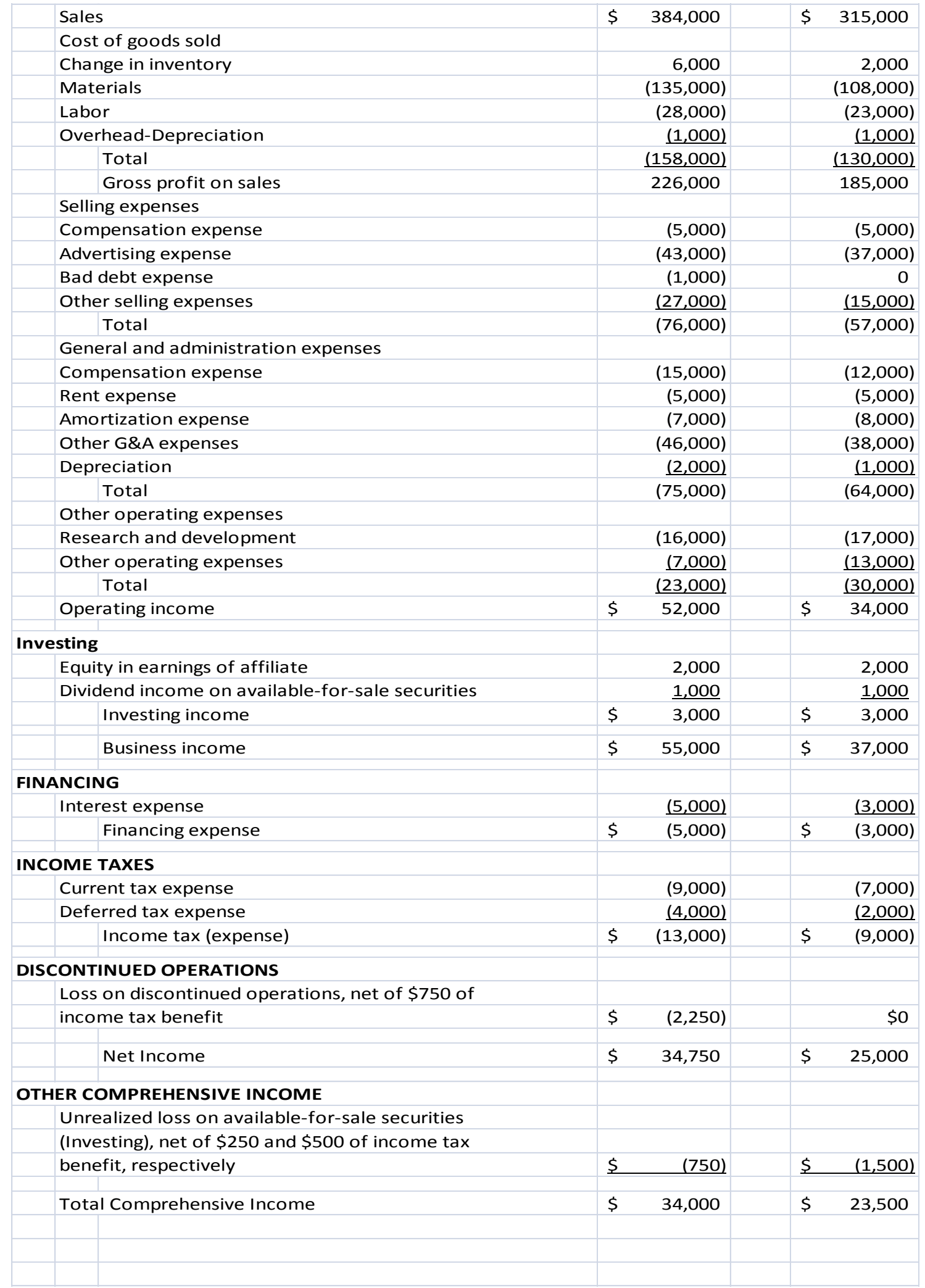




\section{EXHIBIT 4}

Hutch Manufacturing Co. Consolidated Statements of Cash Flow

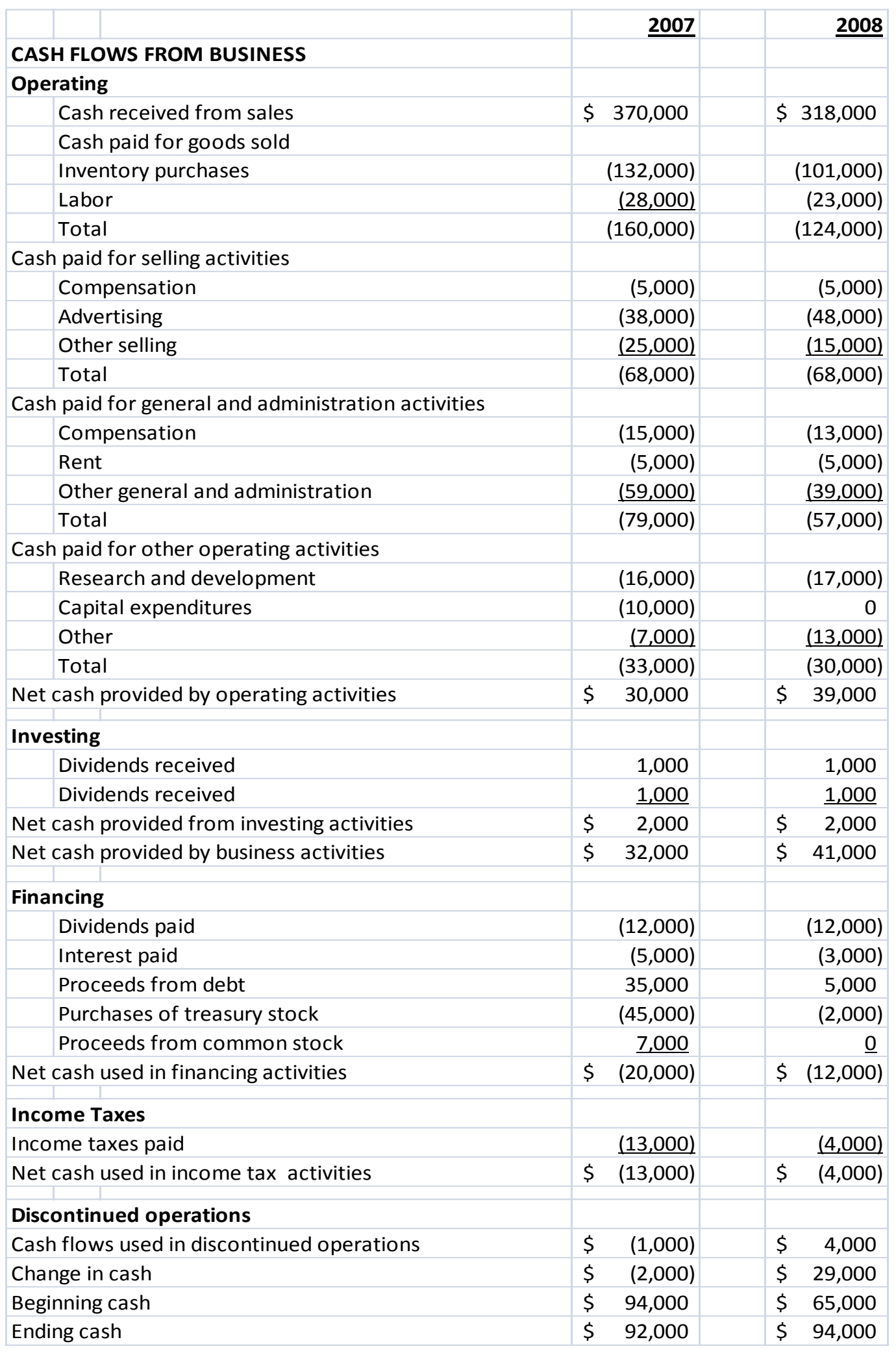




\section{EXHIBIT 5}

Hutch Manufacturing Co. Reconciliation of the Statement of Cash Flows to the Statement of Comprehensive Income

\begin{tabular}{|c|c|c|c|c|c|c|}
\hline & Cash Flows & \begin{tabular}{|l|} 
Accruals, \\
Allocations and \\
other changes
\end{tabular} & \begin{tabular}{|l|} 
Recurring \\
Fair Value \\
Changes
\end{tabular} & \begin{tabular}{|l|} 
Remeasurements \\
Other Than Recurring \\
Fair Value Changes
\end{tabular} & $\begin{array}{l}\text { Comprehensive } \\
\text { Income } \\
(\mathrm{A}+\mathrm{B}+\mathrm{C}+\mathrm{D}) \\
\end{array}$ & \\
\hline & & & & & & \\
\hline Operating & & & & & & Operating \\
\hline Cash received from sales & $\$ 370,000$ & 14,000 & & & 384,000 & Sales \\
\hline \multirow[t]{2}{*}{ Cash paid for goods sold } & & & & & & Cost of goods sold \\
\hline & & 6,000 & & & 6,000 & Change in inventory \\
\hline Inventory purchases & $(132,000)$ & $(3,000)$ & & & $(135,000)$ & Materials \\
\hline \multirow[t]{2}{*}{ Labor } & $(28,000)$ & & & & $(28,000)$ & Labor \\
\hline & & $(1,000)$ & & & $(1,000)$ & Overhead - Depreciation \\
\hline \multirow[t]{2}{*}{ Total } & $(160,000)$ & 2,000 & & & $(158,000)$ & Total \\
\hline & & & & & 226,000 & Gross profit on sales \\
\hline Cash paid for selling activities & & & & & & Selling expenses \\
\hline Compensation & $(5,000)$ & & & & $(5,000)$ & Compensation expense \\
\hline \multirow[t]{2}{*}{ Advertising } & $(38,000)$ & $(5,000)$ & & & $(43,000)$ & Advertising expense \\
\hline & & $(1,000)$ & & & $(1,000)$ & Bad debt expense \\
\hline Other selling & $(25,000)$ & $(2,000)$ & & & $(27,000)$ & Other selling expenses \\
\hline Total & $(68,000)$ & $(8,000)$ & & & $(76,000)$ & Total \\
\hline $\begin{array}{l}\text { Cash paid for general and administration } \\
\text { activities }\end{array}$ & & & & & & Gen \& Admin \\
\hline Compensation & $(15,000)$ & & & & $(15,000)$ & Compensation expense \\
\hline \multirow[t]{2}{*}{ Rent } & $(5,000)$ & & & & $(5,000)$ & Rent expense \\
\hline & & $(7,000)$ & & & $(7,000)$ & Amortization expense \\
\hline \multirow[t]{2}{*}{ Other general and administrative } & $(59,000)$ & 18,000 & & $(5,000)$ & $(46,000)$ & $\begin{array}{l}\text { Other G\&A expenses and goodwill } \\
\text { impairment }\end{array}$ \\
\hline & & $(2,000)$ & & & $(2,000)$ & Depreciation \\
\hline Total & $(79,000)$ & 9,000 & & $(5,000)$ & $(75,000)$ & Total \\
\hline Cash paid for other operating activities & & & & & & Other operating expenses \\
\hline Research and development & $(16,000)$ & & & & $(16,000)$ & Total \\
\hline Capital expenditures & $(10,000)$ & 10,000 & & & & \\
\hline Other & $(7,000)$ & & & & $(7,000)$ & Other operating expenses \\
\hline Total & $(33,000)$ & 10,000 & & & $(23,000)$ & Total \\
\hline Net cash provided by operating activities & 30,000 & 27,000 & & $(5,000)$ & 52,000 & Operating income \\
\hline Investing & & & & & & Investing \\
\hline Dividends received & 1,000 & 1,000 & & & 2,000 & Equity in earnings of affiliate \\
\hline Dividends received & 1,000 & & & & 1,000 & Dividend income on AFS securities \\
\hline Net cash provided from investing activities & 2,000 & 1,000 & & & 3,000 & Investing income \\
\hline Net cash provided by business activities & 32,000 & 28,000 & & & 55,000 & Business income \\
\hline Financing & & & & & & Financing \\
\hline Interest paid & $(5,000)$ & & & & $(5,000)$ & Interest expense \\
\hline \multirow[t]{2}{*}{ Proceeds from debt } & 35,000 & $(35,000)$ & & & & \\
\hline & & & & & $(5,000)$ & Financing expense \\
\hline Income Taxes & & & & & & Income Taxes \\
\hline \multirow[t]{2}{*}{ Income taxes paid } & $(13,000)$ & 4,000 & & & $(9,000)$ & Current tax expense \\
\hline & & $(4,000)$ & & & $(4,000)$ & Deferred tax expense \\
\hline Net cash used in income tax activities & $\$ \quad(13,000)$ & & & & $(13,000)$ & Income tax expense \\
\hline Discountinued Operations & & & & & & Discountinued Operations \\
\hline \multirow[t]{3}{*}{ Cash flows used in discountinued operations } & $\$ \quad(1,000)$ & & & $(1,250)$ & $(2,250)$ & Loss on discountinued operations \\
\hline & & & & & & Other Comprehensive Income \\
\hline & & & $(750)$ & & $(750)$ & Unrealized loss on AFS securities \\
\hline $\begin{array}{l}\text { Net cash provided by activities with non- } \\
\text { equity holders }\end{array}$ & 48,000 & $(7,000)$ & $\$ \quad(750)$ & $(6,250)$ & 34,000 & Total Comprehensive Income \\
\hline & & & & & & \\
\hline & & & & & & \\
\hline
\end{tabular}




\section{NOTES}

